\title{
Using Analytic Network Process in a Group Decision-Making for Supplier Selection
}

\author{
Mohammadreza SADEGHI ${ }^{1}$, Mohammad ali RASHIDZADEH ${ }^{2}$, \\ Mohammad ali SOUKHAKIAN ${ }^{2}$ \\ ${ }^{1}$ Department of Industrial Management, Faculity of Management and Accounting \\ Allameh Tabatabaei University \\ Nezamiganjavistreer, Tavanirstreet, Tehran, Iran \\ ${ }^{2}$ Faculty of Economics, Management and Social Sciences, Shiraz University \\ Daneshjoo Street, Shiraz University, Shiraz, Iran \\ e-mail:m.r.sadeghi61@gmail.com
}

Received: April 2011; accepted: April 2012

\begin{abstract}
Nowadays most required products and services of companies are provided through other organisations. Outsourcing as a new approach has a significant role in management literature. Supplier should be selected by executives, when the organization decides to acquire a product or service from other organizations. Concerning supplier selection, the managers should consider more than one factor or criterion, which may be inconsistent and contradictory. Therefore, supplier selection is a multi-criteria decision-making issue. Analytic network process (ANP) is a technique to solve multi-criteria decision-making problems in which the criteria affect each other and have nonlinear correlation. In this study, the goal is to use ANP to select the supplier in a group decision-making.
\end{abstract}

Keywords: supply chain management, outsourcing, supplier selection, analytic network process, group decision-making.

\section{Introduction}

The achievement of a sustainable competitive advantage has long been the goal of companies and organizations. This "holy grail" has attracted widespread attention over the last few decades (Porter, 1985). Much of this attention has shifted to supply chain. Supply chain has become an important issue in organization management literature (Christopher, 1992). The importance of supply chain has increased so much that some researchers has claimed that competitive advantage may be gained through developing strong network of companies either through horizontal associations, joint venture agreements or through close supply relationships (Harland, 1996).

As evidence to afore-mentioned claim, some of the world's most successful organizations gain competitive advantage through their direct and indirect network of suppliers (Hines, 1997). Toyota is an example, which increased its productivity over $80 \%$ by effective use of its supplier networks (Esain and Hines, 1997).

Organizations usually provide their required materials, products or services in the supply chain by following three strategies: 
1. Producing these materials or services by themselves.

2. Providing services or material through strategic partnerships.

3. Providing services or material through outsourcing.

Outsourcing is one of the methods to form supplier network and achieve competitive advantage. Outsourcing is a very successful and increasingly popular enterprise management strategy (Koszewska, 2004). It occurs when the execution of tasks, function and processes hitherto fulfilled in-house is commissioned to an external provider specializing in given area based on long-term cooperation. Outsourcing is also defined as the operation of shifting an internal transaction to an external supplier through a long-term contract (Quelin and Duhamel, 2003).

Outsourcing dates back to the 1970s. Initially it was only involved IT-related issues, but gradually more and more enterprises realized that they could not be experts in more than one or two fields. This made them cast aside various areas of activities and entrust them to specialists. According to a survey by Fortune magazine, over $90 \%$ of business organizations today take advantage of external service providers. This survey shows that only in the European market, the 2001 estimation of such services was US \$27 billion, which is increasing from year to year. Originally, only large corporations used outsourcing, but nowadays it is becoming more and more popular among small-sized enterprises (Koszewska, 2004).

When an organization decides to acquire a product or service from other organizations, supplier selection will be an important issue. Indeed, decision-making in supplier selection is a crucial subject in outsourcing. Supplier selection is a multi-criteria decisionmaking problem since the decision-maker should consider various contradictory criteria. It means that optimizing one criterion may cause some other ones go far from optimization. Some of these criteria are quality, cost, satisfaction of customer and brand.

There are different methods to solve multi-criteria decision-making problems. AHP and ANP are two methods introduced by Tomas Saaty. AHP tries to solve the decision problem by modeling it in a hierarchy while ANP is used when the problem is so complex that cannot be modeled as a hierarchy. This complexity occurs because of the effect of criteria on each other or the effect of alternatives on criteria. Since in supplier selection criteria affect each other (for example changing in quality affects the costs), in this study ANP is used for the supplier selection.

In this study, the goal is to present a method to select supplier through (ANP) in a group decision-making. In the next part a review of studies using ANP or AHP in supplier selection is presented. In part three ANP is clarified through comparing with AHP. In the final part ANP is applied in a group decision-making to select supplier in a case study.

\section{Literature Review}

A quick review of supplier selection models in outsourcing literature shows that many researches proposed methods based on AHP and ANP to solve the supplier selection problems. In this section, a brief review of these works is presented. 
Some of the researchers have proposed AHP to deal with the supplier selection problem: Akarte et al. (2001) developed a web-based AHP system to evaluate the casting suppliers with respect to 18 criteria. Muralidharan et al. (2002) proposed a five-step AHP-based model to aid decision makers in rating and selecting suppliers with respect to nine evaluating criteria. Chan and Chan (2004) applied AHP to evaluate and select suppliers. Liu and Hai (2005) applied AHP to evaluate and select suppliers; Similar to Chan (2003), the authors did not apply the AHP's pairwise comparison to determine the relative importance ratings among the criteria and sub-factors. Instead, the authors used Noguchi's voting and ranking method, which allowed every manager to vote or to determine the order of criteria instead of the weights. Chan et al. (2007) developed an AHP-based decision making approach to solve the supplier selection problem. Potential suppliers were evaluated based on 14 criteria. Hou and Su (2007) proposed an AHPbased decision support system for the supplier selection problem in a mass customization environment.

Some of the suggested approaches have used ANP to tackle the supplier selection problem: Sarkis and Talluri (2002) believed that supplier-evaluating factors would influence each other, and the internal interdependency needed to be considered in the evaluation process. Bayazit (2006) proposed an ANP model to tackle the supplier selection problem. There were ten evaluating criteria in the model, which were classified into supplier's performance and capability clusters. Gencer and Gurpinar (2007) implemented an ANP model in an electronic company to evaluate and select the most appropriate supplier with respect to various supplier-evaluating criteria, which were classified into three clusters. Lee et al. (2009a) proposed a model, which applies the ANP and the benefits, opportunities, costs and risks (BOCR) concept, is constructed to consider various aspects of buyer-supplier relationships. Multiple factors that affect the success of the relationship are analyzed by incorporating experts' opinions on their priority of importance, and a performance ranking of the buyer-supplier forms is obtained. Liao et al. (2010) by considering the interdependence among the selection criteria, applied the ANP to help Taiwanese TV companies to effectively select optimal program suppliers.

Some studies integrated AHP approaches to evaluate the performance of suppliers and select the best supplier. Chen and Huang (2007) integrated AHP and a multi-attribute negotiation mechanism for the supplier selection problem. Ramanathan (2007) suggested that Data Envelopment Analysis (DEA) could be used to evaluate the performance of suppliers using both quantitative and qualitative information obtained from the total cost of ownership and AHP. Saen (2007) proposed an integrated AHP-DEA approach to evaluate and select slightly non-homogeneous suppliers. Sevkli et al. (2007a) applied an integrated AHP-DEA approach for supplier selection. In the approach, AHP was used to derive local weights from a given pairwise comparison matrice, and aggregate local weights to yield overall weights. Ha and Krishnan (2008) applied an integrated approach in an auto parts manufacturing company for supplier selection. Twelve evaluating criteria were proposed for the selection problem. In the approach, AHP was used first to evaluate the performance of suppliers with respect to five qualitative fac- 
tors. Then, the remaining seven quantitative criteria along with the scores for each supplier calculated by AHP were passed to DEA and artificial neural network (ANN) to measure the performance efficiency of each supplier. Cebi and Bayraktar (2003) proposed AHP to evaluate the relative performance of suppliers for every raw material with respect to 14 evaluating criteria. The weightings of suppliers were then used as the input of a Goal Programming (GP) model to select the best set of suppliers for a particular type of raw materials, and determine the amount of raw materials to be purchased. Similar to Cebi and Bayraktar (2003), Wang et al. (2004, 2005) applied an integrated AHP-GP approach for supplier selection. The only difference between them is due to the evaluating criteria used in AHP. The AHP weightings were incorporated into one of the goal constraints of the GP model. Percin (2006) applied an integrated AHP-GP approach for supplier selection. AHP was used first to measure the relative importance weightings of potential suppliers with respect to 20 evaluating factors. Kull and Talluri (2008) utilized an integrated AHP-GP approach to evaluate and select suppliers with respect to risk factors and product life cycle considerations. Mendoza et al. (2008) presented an integrated AHP-GP approach to reduce a large number of potential suppliers to a manageable number, rank the alternative suppliers with respect to five evaluating criteria, and determine the optimal order quantity. Yang and Chen (2006) applied AHP to compute relative importance weightings of qualitative criteria. The weightings were then used as coefficients of grey relational analysis model. Mendoza and Ventura (2008) proposed a two-stage method to deal with the supplier selection and order quantity problems simultaneously. Xia and Wu (2007) incorporated AHP into the multi-objective mixed integer programming model for supplier selection.

Some other approach integrated ANP with other mathematical technique to solve the supplier selection approach: Demirtas and Ustun (2008) developed an integrated ANP and multi-objective mixed integer linear programming approach to select the best set of suppliers, and to determine the optimal order allocation. Lin et al. (2011) applied a methodology of ANP, technique for order preference by similarity to ideal solution (TOPSIS) and linear programming (LP) in the supplier selection process. Demirtas and Ustun (2009) developed an integrated ANP and GP approach for supplier selection. Similar to Demirtas and Ustun (2008), potential suppliers were evaluated using ANP first. The weightings were then used as coefficients of one of the three objective functions. All evaluating criteria and objective functions are exactly the same as those in Demirtas and Ustun (2008). The only difference is that a GP model was constructed in which there were four goals. Lang et al. (2009) proposed a hierarchical evaluation framework to assist the expert group to select the optimal supplier in supply chain management strategy (SCMS). The rationales for the evaluation framework are based upon (i) multi-criteria decision making (MCDM) analysis that can select the most appropriate alternative from a finite set of alternatives with reference to multiple conflicting criteria, (ii) ANP and (iii) choquet integral a non-additive fuzzy integral that can eliminate the interactivity of expert subjective judgment problems. 


\section{Analytic Network Process (ANP)}

\subsection{Introduction to ANP}

AHP models the decision-making problem as a hierarchy in a top-down approach. AHP have been applied in scientific researches for solving MADM problems. For instance Chang et al. (2007), Hsu and Pan (2009), Huang (2009), Huang et al. (2009), Kuo et al. (2008), Sevkli et al. (2007b), Sun et al. (2008), Levary (2008), Li et al. (2008), Hu et al. (2008), Naesens et al. (2009) and Tsai and Hung (2009) are some studies that used AHP to solve a MADM problem. Many decision-making problems couldn't be structured hierarchically because they involve the interaction and dependency of higher-level element. In these problems not only does the importance of the criteria determine the importance of the alternatives, but also the importance of the alternatives themselves determine the importance of the criteria (Saaty, 1996a). To solve these problems, ANP can be used. ANP, developed by Saaty in 1996, is the first mathematical theory that makes it possible for decision-maker to deal systematically with this kind of dependence and feedback (Ozturk, 2006)

\subsection{Using Network Instead of Hierarchy}

As mentioned, the advantage of ANP is the capability of solving the problems in which alternatives and criteria have such interactions that cannot be shown in a hierarchy. When the decision-maker decides to model a problem as a network, it is not necessary to specify levels (Bauyaukyazici and Sucu, 2003). A network contains clusters (components, nodes or criteria) and elements (sub criteria) in these clusters. However, in creating structures to represent problems there may be a system larger than components. According to size, there is a system that is made up of subsystems and each subsystem made up of elements (Saaty and Vargas, 2006). The differences between a hierarchy and a network are shown in Fig. 1 (Azis, 2003).

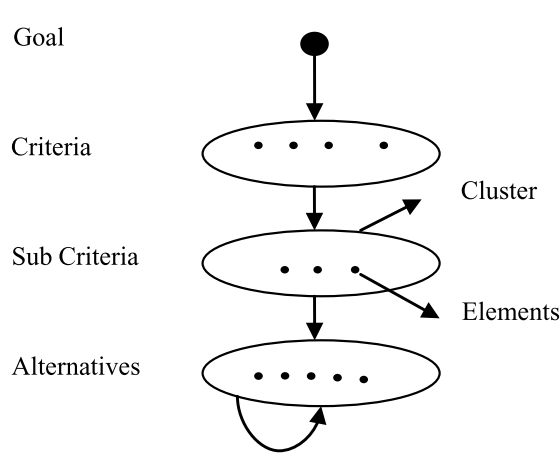

Hierarchy of decision-making

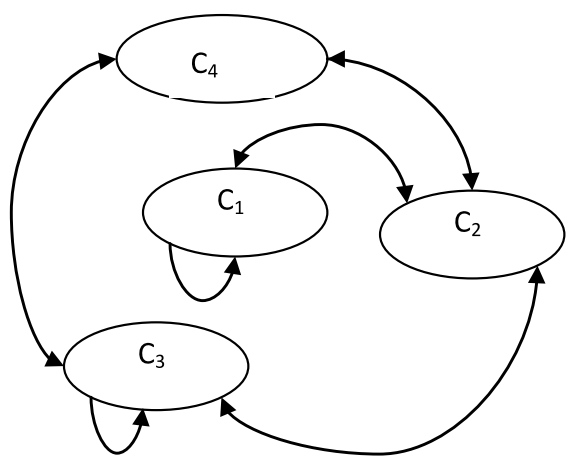

Network of decision-making

Fig. 1. The differences between hierarchy and network of decision-making. 


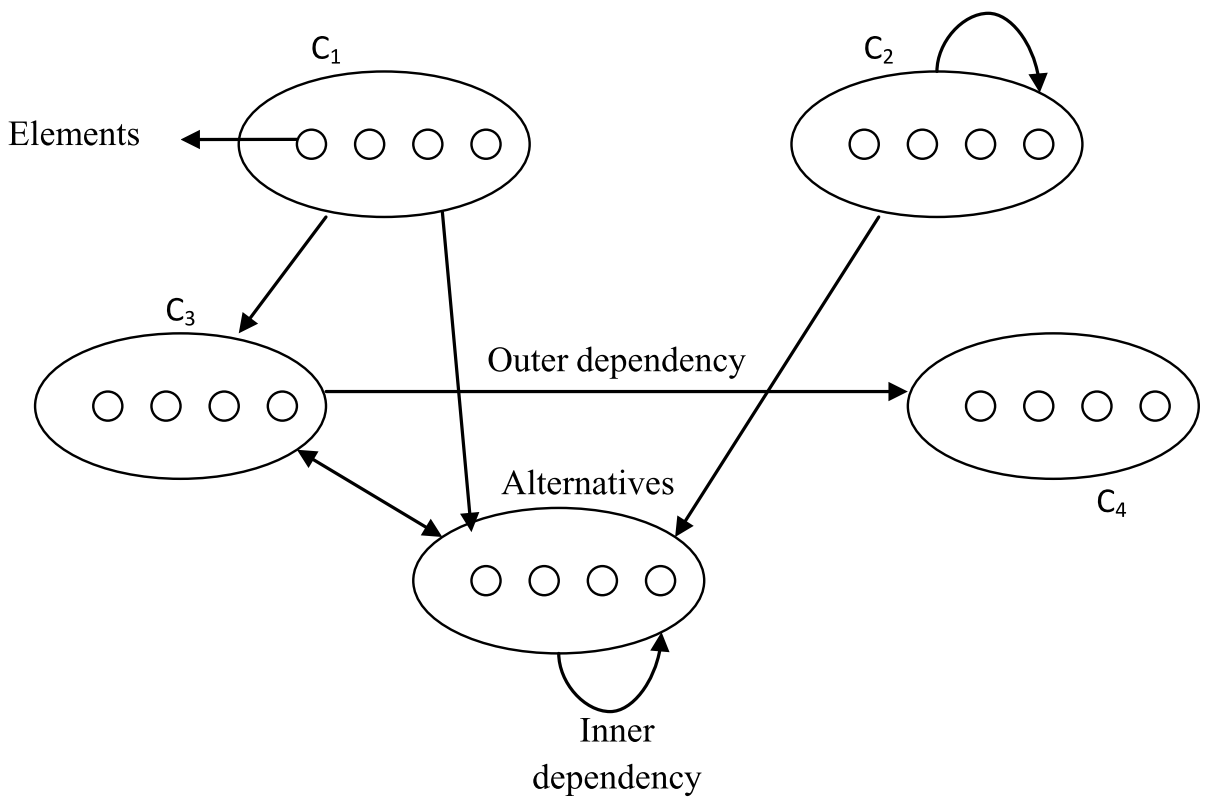

Fig. 2. Different kinds of cluster and dependency in a network.

As shown in Fig. 1, in AHP interactions and dependencies can start from the upper levels through lower levels. However, in ANP all of the elements of network can interact on each other. In fact, AHP uses a kind of network, interactions of which are only linear and top-down.

There are three kinds of clusters in a network. Those clusters with no enter arrows, are source clusters such as $C_{1}$ and $C_{2}$ (Fig. 2) and Those from which no arrow leaves are known as sink clusters such as $C_{4}$ and finally those which arrows enter and exit, are known as transient cluster such as $C_{3}$.

There are two kinds of dependency (interaction) in a network: inner dependency and outer dependency. Outer dependency occurs when the elements of a cluster affect the other cluster's elements and there is inner dependency when some elements of one cluster affect each other (sometimes called loop) (Saaty and Takizawa, 1986). Different kinds of dependency and components are shown in Fig. 2.

Classification of elements into clusters can be done according to their homogeneity. For example if you want to make a network for decision-making to buy a machine for production line, the different kinds of costs should be put in a cluster, containing elements such as purchasing and maintenance cost.

To detect the interaction and dependency, decision-maker can use input-output analysis. Leontief proposed the input-output analysis in analyzing the US economy. Inputoutput analysis explained the interconnection among sectors of complex economic systems, which may be national, regional, or enterprise type (Li and Liu, 2008). 


\subsection{Supermatrix in ANP}

Although ANP and AHP are similar in the comparative judgment phase, they are different in the synthesizing phase. In the ANP, ratio scale priority vectors (derived from pair-wise comparison matrices) are not synthesized linearly as in AHP. Saaty has an improved "supermatrix" technique to synthesize ratio scales. Each ratio scale is appropriately introduced as a column in a matrice to represent the impact of elements in a cluster on an element in another cluster (outer dependence) or on elements of the cluster itself (inner dependence). In that case, the supermatrix is composed of several sub-matrices which each columns is a principal eigenvector that represents the impact of all elements in a cluster on each elements in another (or the same) cluster. Let the clusters of a decision system be $C_{h}, h=1,2, \ldots, n$, and each cluster $h$ has $n_{h}$ elements, denoted $c_{h 1}, c_{h 2}, \ldots, c_{h n h}$, then the supermatrix of such a network will be like Fig. 3 (Lee et al., 2009b).

The $i, j$ block of supermatrix is shown in Fig. 4. Vectors that form this matrix are ratio scale priority vectors derived by pair-wise comparison matrices. These comparison matrices demonstrate the judgment of decision-maker about the priority of elements. It is not necessary that every element of a cluster has an influence on an element in another cluster. In such a case, these elements are given a zero value for their contribution.

For deriving judgment of the decision-maker and establishing the comparison matrices, the scale that was suggested by Saaty for AHP and ANP can be used. These scales are shown in Table 1 (Lin et al., 2008).

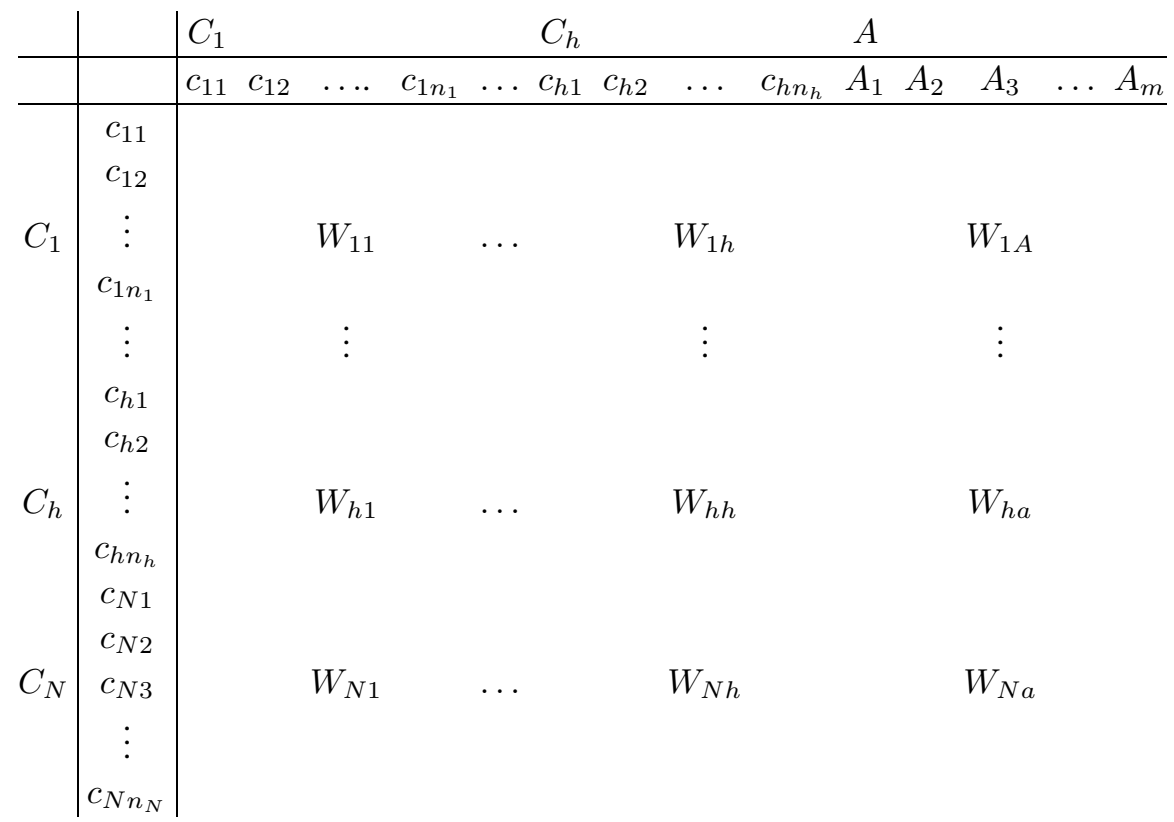

Fig. 3. A supermatrix of a network. 


$$
\begin{gathered}
\text { M. Sadeghi et al. } \\
W_{i j}=\left|\begin{array}{cccc}
W_{i 1}^{j 1} & W_{i 1}^{j 2} & \ldots & W_{i 1}^{j n_{j}} \\
W_{i 2}^{j 1} & W_{i 2}^{j 2} & \ldots & W_{i 2}^{j n_{j}} \\
\vdots & \vdots & \ldots: & \vdots \\
W_{i n_{i}}^{j 1} & W_{i n_{i}}^{j 2} & \ldots & W_{i n_{i}}^{j n_{j}}
\end{array}\right|
\end{gathered}
$$

Fig. 4. $i, j$ block of a network's supermatrix.

Table 1

Scale for comparison matrice

\begin{tabular}{ll}
\hline Verbal scale & Intensity of importance \\
\hline Extreme importance & 9 \\
Very strong importance & 7 \\
Strong importance & 5 \\
Moderate importance & 3 \\
Equal importance & 1 \\
Intermediate values & $8,6,4,2$ \\
\hline
\end{tabular}

\subsection{Group Decision-Making in ANP and AHP}

Some time it is necessary to make a decision by more than one person. In such cases, group decision-making technique is used to integrate the judgments of decision-makers. $\mathrm{Xu}$ (2000) suggested that a ratio scale priority vector for each decision-maker's comparison matrice should be calculated, then these calculated vectors could be integrated to achieve a single priority vector. But Lin et al. (2008) proved that, the comparison matrices should be integrated to achieve a final comparison matrice followed by calculation of priority vector for final comparison matrices.

Therefore in AHP and ANP a final comparison matrice indicating the judgments of decision-makers on the pair-wise comparisons should be calculated in group decisionmaking. Then, the ratio scale priority vectors of the final comparison matrice should be figured out. Now these caculated vectors should be put in their appropriate positions in the supermatrix. The elements of the final comparison matrice are calculated through the geometric mean of elements in comparison matrice of each decision-maker (see (1); Azar and Rajabzade, 2002).

$$
A_{i j}^{\prime}=\left(\prod_{k=1}^{m} A_{i j}^{w_{k}}\right)^{\sum^{1} w_{k}} .
$$


In (1), $w_{i}$ is the weight given to each decision-makers' opinion (matrice) and $\mathrm{m}$ is the number of decision makers. Each person's weight is determined by some factors such as the person's experience, knowledge, background, etc. $A_{i j}$ indicates the elements of the decision-makers' comparison matrices and $A_{i j}^{\prime}$ indicates the elements of the final comparison matrice.

\subsection{Calculating the Final Weights of the Alternatives and the Criteria}

As mentioned before, the supermatrix has some blocks. Columns of each block is a vector indicating the impact of the elements of the left side corresponding cluster on the elements at the top of the supermatrix. To have a stochastic supermatrix, clusters should be compared with each other. The resulting priorities of the clusters are used to weight the corresponding blocks. Through this, the supermatrix becomes column stochastic (Saaty, 1996b).

It should be noted that only the direct interaction between elements are shown by synthesizing ratio scale priority vectors derived from pair-wise comparison matrices in a network. Elements could interact either directly or indirectly in systems-with-feedback. As an example, some four elements (as A, B, C and D) and their various impacts on each other are shown in Fig. 5.

The total impact of A on B consists of many components. The direct impact (or first order impact) of A on B is represented with a solid line in Fig. 5. All the first order impacts can be obtained directly from the supermatrix. There are also some indirect impacts of A on B through a third element. For instance, there is an impact of A on B through C. In Fig. 5, this second order impacts is represented with dotted gray lines. The contribution of this indirect impacts from the total second order impact of $\mathrm{A}$ on $\mathrm{B}$ can be obtained by multiplying the impact of $\mathrm{A}$ on $\mathrm{C}$ by the impact of $\mathrm{C}$ on $\mathrm{B}$. Another second order impact of A on B is through D. This second order impact is represented with dotted black lines. The last second order impact of $\mathrm{A}$ on $\mathrm{B}$ is through the impact of $\mathrm{A}$ on itself and then on $\mathrm{B}$. This second order impact is represented with solid gray lines. The total of the second order impacts can be obtained from the square of the supermatrix. As can be seen in Fig. 5, there

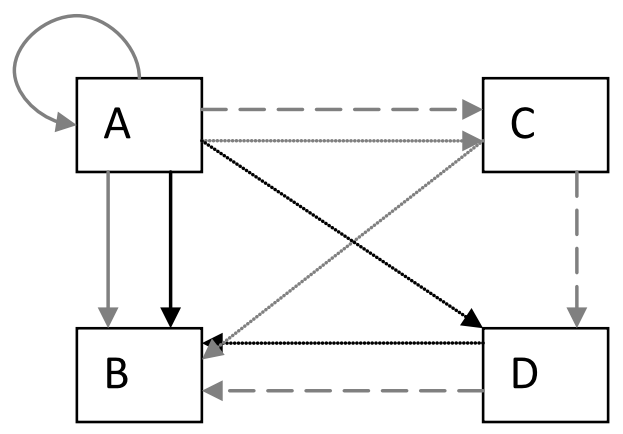

Fig. 5. Different kinds of interaction in a network. 
is also a third order impact of A on B represented with dashed lines. The contribution of third order impact from the total third order impact of A on B can be obtained by multiplying the impact of $\mathrm{A}$ on $\mathrm{C}$ by the impact of $\mathrm{C}$ on $\mathrm{D}$ and by the impact of $\mathrm{D}$ on $\mathrm{B}$. The total of third order impacts could be obtained from the third power of the supermatrix, and the fourth and next order impacts are obtained in the same way. Thus the limiting power of the supermatrix which is column stochastic should be computed. This concept is parallel to the Markov chain process (Meade and Sarkis, 1998). The limiting power of the supermatrix has an equilibrium distribution, as in the Markov chain process. Alternatives in the model can be ordered using limiting priorities obtained from the equilibrium distribution of the supermatrix.

\section{Case Study}

Fars Gas Company (FGC) provides many of its required products and services from outer suppliers. Gas counter is one of these products. Companies which own the required technology to produce gas counters, are Iran National Gas Industry (INGI), Iran Gas Industry (IGI), Gas Suzan (GS), Para Sanat (PS) and Hadid Saze Pishro (HSP). The authority of selecting the supplier is delegated to a committee called the Commercial and Technical Committee (CTC). Supplier was previously selected through CTC members only based on the suggested price of companies in tenders. Recently the company has faced problems with the gas counters provided in this way. An example of such a problem is repetitive failures in gas counters. Therefore, they decided to use another method to select gas counter supplier. As a contribution to the supplier selection process, the current study uses ANP to select the supplier regarding some other factors in addition to mere price factor. The process of supplier selection by ANP is described in the below stepwise manner:

\section{Step 1. Weighting the CTC members}

At the first stage, considering the experiment and knowledge of the six members of CTC, a weight was given to each of the members. Three members were given a weight equal to two and the other three members were given the weight one.

\section{Step 2. Determining the important criteria to select the supplier}

In this stage, interviews with CTC's members were conducted to determine the criteria for selecting the gas counter supplier. In these interviews, Delphi method was used. At last, thirteen criteria were recognized. After making sure that all the members of CTC have a common understanding of the criteria regarding the information obtained from the interviews, the criteria were classified in to three categories (clusters). These clusters were: (1) commercial criteria, (2) commercial and technical criteria and (3) technical criteria. The criteria and their definitions are shown in Table 2. 
Table 2

Criteria and sub criteria for supplier selection in FGC

\begin{tabular}{|c|c|c|}
\hline Criteria & Subcriteria & Definition \\
\hline \multirow{2}{*}{$\begin{array}{l}\text { Commercial } \\
\text { criteria }\end{array}$} & Price $(\mathrm{P})$ & The price that the suppliers suggest in the tender \\
\hline & $\begin{array}{l}\text { Delivery insurance } \\
\text { (DI) } \\
\text { Economic power } \\
\text { (EP) }\end{array}$ & $\begin{array}{l}\text { How has the supplier fulfilled its commitments in the previous contracts } \\
\text { considering time and quality factors of the delivery? } \\
\text { How does the supplier guaranty economically to deliver the ordered } \\
\text { products in time? }\end{array}$ \\
\hline \multirow{4}{*}{$\begin{array}{l}\text { Commercial } \\
\text { and technical } \\
\text { criteria }\end{array}$} & $\begin{array}{l}\text { Quality assurance } \\
\text { (QI) }\end{array}$ & How does the supplier respond to its quality assurance services? \\
\hline & $\begin{array}{l}\text { Long-term } \\
\text { relations (LR) }\end{array}$ & $\begin{array}{l}\text { The duration of the supplier's previous relations with FGC before this } \\
\text { tender }\end{array}$ \\
\hline & $\begin{array}{l}\text { Management } \\
\text { quality (MQ) }\end{array}$ & $\begin{array}{l}\text { The ability of the supplier's management in communicating with FGC's } \\
\text { management in previous contracts }\end{array}$ \\
\hline & Experience $(\mathrm{E})$ & How much is the supplier experienced in gas counter production? \\
\hline \multirow[t]{6}{*}{$\begin{array}{l}\text { Technical } \\
\text { criteria }\end{array}$} & $\begin{array}{l}\text { Technical } \\
\text { equipment (TE) }\end{array}$ & The extent to which supplier updates its equipments \\
\hline & $\begin{array}{l}\text { Technical } \\
\text { personals (TP) }\end{array}$ & The Technical knowledge and experience of the supplier's personnel \\
\hline & $\begin{array}{l}\text { Financial power } \\
\text { (FP) }\end{array}$ & $\begin{array}{l}\text { The financial power of the supplier for providing the needed technology } \\
\text { and knowledge of counter production }\end{array}$ \\
\hline & $\begin{array}{l}\text { Satisfaction of } \\
\text { FGC personals } \\
(\mathrm{SP})\end{array}$ & $\begin{array}{l}\text { The FGC's technical personnels' satisfaction degree from previous con- } \\
\text { tracts }\end{array}$ \\
\hline & $\begin{array}{l}\text { Technical } \\
\text { standards and } \\
\text { quality (TSQ) }\end{array}$ & The quality of the supplier's product(s) \\
\hline & Audit degree (AD) & The grade that CTC gives to the supplier after the anual audition \\
\hline
\end{tabular}

\section{Step 3. Designing the network of decision}

In this stage, an input-output analysis was made. To do this, interviews with CTC's members were conducted. Then, an input-output matrice (the entries or elements of which are zero and one) was designed. Number one symbolize the existence of corresponding row element impact on the corresponding column element and zero showed that there is no impact. With the help of input-output matrice, the network was designed as shown in Fig. 6.

\section{Step 4. Deriving the CTC's members' judgments from comparison matrices and establishing the supermatrix}

In this stage, considering the input-output analysis and decision network a questionnaire was designed to derive pair-wise comparison judgments.

The comparison matrices among the elements were integrated using equation 1 after the CTC members answered the questionnaires. This led to the final comparison matrices to achieve the ratio scale vectors. The supermatrix was established after putting these ratio scale vectors in their appropriate positions (Table 3). 
Table 3 (Part I)

The supermatrix of decision-making in FGC for supplier selection

\begin{tabular}{|c|c|c|c|c|c|c|c|c|c|c|}
\hline & & Goal & $\mathrm{p}$ & DI & EP & QI & LR & MQ & $\mathrm{E}$ & $\mathrm{TE}$ \\
\hline & Goal & 0 & 0 & 0 & 0 & 0 & 0 & 0 & 0 & 0 \\
\hline \multirow[t]{3}{*}{ Commercial criteria } & $P$ & 0.51472 & 0 & 0.38743 & 0.69098 & 0.27429 & 0.16952 & 0 & 0.47273 & 0.13595 \\
\hline & DI & 0.24264 & 0.20521 & 0 & 0.30902 & 0.36285 & 0.41524 & 0.5 & 0.19299 & 0.20546 \\
\hline & EP & 0.24264 & 0.79479 & 0.61257 & 0 & 0.36285 & 0.41524 & 0.5 & 0.33427 & 0.65859 \\
\hline \multirow{4}{*}{$\begin{array}{l}\text { Commercial and } \\
\text { technical criteria }\end{array}$} & QI & 0.35162 & 0.13901 & 0 & 0.12681 & 0 & 0.3469 & 0 & 0.31865 & 0.18608 \\
\hline & LR & 0.1195 & 0.24078 & 0.388 & 0.25988 & 0.21115 & 0 & 0.38649 & 0.30323 & 0 \\
\hline & MQ & 0.29938 & 0.22701 & 0.388 & 0.27782 & 0.5193 & 0.41333 & 0 & 0.37812 & 0.48946 \\
\hline & $\mathrm{E}$ & 0.2295 & 0.39319 & 0.22401 & 0.3355 & 0.26954 & 0.23977 & 0.61351 & 0 & 0.32446 \\
\hline \multirow[t]{6}{*}{ Technical criteria } & $\mathrm{TE}$ & 0.13713 & 0.27647 & 0.34045 & 0 & 0.19723 & 0.11136 & 0.20327 & 0 & 0 \\
\hline & TP & 0.17661 & 0.22604 & 0.24594 & 0.41551 & 0.26995 & 0.11971 & 0.3341 & 0 & 0.36689 \\
\hline & FP & 0.10331 & 0.20154 & 0.18417 & 0.37059 & 0.21351 & 0.16481 & 0.18552 & 0.49046 & 0.63311 \\
\hline & SP & 0.14157 & 0 & 0.06643 & 0 & 0 & 0.16946 & 0 & 0 & 0 \\
\hline & TSQ & 0.22644 & 0.29595 & 0.16301 & 0.2139 & 0.31932 & 0.20658 & 0.27711 & 0.50954 & 0 \\
\hline & $\mathrm{AD}$ & 0.21494 & 0 & 0 & 0 & 0 & 0.22808 & 0 & 0 & 0 \\
\hline \multirow[t]{5}{*}{ Alternatives } & INGI & 0 & 0.17386 & 0.08574 & 0.0494 & 0.21844 & 0.295 & 0.13476 & 0.28947 & 0.18472 \\
\hline & IGI & 0 & 0.17137 & 0.18188 & 0.20959 & 0.30774 & 0.13844 & 0.31259 & 0.09211 & 0.25283 \\
\hline & GS & 0 & 0.21898 & 0.4455 & 0.44461 & 0.31958 & 0.39043 & 0.3686 & 0.36842 & 0.29254 \\
\hline & PS & 0 & 0.21681 & 0.10501 & 0.1482 & 0.07538 & 0.07485 & 0.08203 & 0.11842 & 0.13496 \\
\hline & HSP & 0 & 0.21898 & 0.18188 & 0.1482 & 0.07886 & 0.10127 & 0.10201 & 0.13158 & 0.13496 \\
\hline
\end{tabular}


Table 3 (Part II)

The supermatrix of decision-making in FGC for supplier selection

\begin{tabular}{|c|c|c|c|c|c|c|c|c|c|c|c|}
\hline & & $\mathrm{TP}$ & FP & SP & TSQ & $\mathrm{AD}$ & INGI & IGI & GS & PS & HSP \\
\hline & Goal & 0 & 0 & 0 & 0 & 0 & 0 & 0 & 0 & 0 & 0 \\
\hline \multirow[t]{3}{*}{ Commercial criteria } & $\mathrm{P}$ & 0.22421 & 0.72727 & 0 & 0.43801 & 0 & 0.55051 & 0.17588 & 0.29591 & 0.13657 & 0.1616 \\
\hline & DI & 0 & 0.09091 & 0.71472 & 0.11542 & 1 & 0.22474 & 0.39329 & 0.34168 & 0.33452 & 0.39584 \\
\hline & $\mathrm{EP}$ & 0.77579 & 0.18182 & 0.28528 & 0.44658 & 0 & 0.22474 & 0.43083 & 0.36241 & 0.52892 & 0.44256 \\
\hline \multirow{4}{*}{$\begin{array}{l}\text { Commercial and } \\
\text { technical criteria }\end{array}$} & QI & 0.16098 & 0.20408 & 0.32042 & 0.24911 & 0.35203 & 0.1664 & 0.3872 & 0.23085 & 0.23363 & 0.29246 \\
\hline & LR & 0.18075 & 0.42854 & 0.19204 & 0.16209 & 0 & 0.32792 & 0.19367 & 0.22367 & 0.2851 & 0.25251 \\
\hline & MQ & 0.41087 & 0.36738 & 0.32042 & 0.4125 & 0.48293 & 0.19092 & 0.24546 & 0.28957 & 0.18303 & 0.24139 \\
\hline & $\mathrm{E}$ & 0.2474 & 0 & 0.16713 & 0.17629 & 0.16504 & 0.31476 & 0.17367 & 0.25591 & 0.29824 & 0.21365 \\
\hline \multirow[t]{6}{*}{ Technical criteria } & $\mathrm{TE}$ & 0.33901 & 0.52821 & 0.24543 & 0.25769 & 0.24616 & 0.18487 & 0.15885 & 0.16884 & 0.17759 & 0.15124 \\
\hline & $\mathrm{TP}$ & 0 & 0.47179 & 0.24959 & 0.32901 & 0.28798 & 0.20553 & 0.1562 & 0.17462 & 0.20656 & 0.20355 \\
\hline & FP & 0.66099 & 0 & 0.16335 & 0.21785 & 0.17787 & 0.16966 & 0.18725 & 0.16809 & 0.19608 & 0.16698 \\
\hline & SP & 0 & 0 & 0 & 0.08634 & 0 & 0.10807 & 0.1196 & 0.14789 & 0.11213 & 0.16981 \\
\hline & TSQ & 0 & 0 & 0.34163 & 0 & 0.28798 & 0.1656 & 0.14904 & 0.16884 & 0.19551 & 0.18436 \\
\hline & $\mathrm{AD}$ & 0 & 0 & 0 & 0.1091 & 0 & 0.16627 & 0.22905 & 0.17171 & 0.11213 & 0.12406 \\
\hline \multirow[t]{5}{*}{ Alternatives } & INGI & 0.14979 & 0.19962 & 0.18708 & 0.2325 & 0.21117 & 0 & 0 & 0 & 0 & 0 \\
\hline & IGI & 0.19835 & 0.26509 & 0.22154 & 0.23661 & 0.23473 & 0 & 0 & 0 & 0 & 0 \\
\hline & GS & 0.30475 & 0.34869 & 0.35049 & 0.29531 & 0.32602 & 0 & 0 & 0 & 0 & 0 \\
\hline & PS & 0.16632 & 0.09208 & 0.08447 & 0.11472 & 0.09869 & 0 & 0 & 0 & 0 & 0 \\
\hline & HSP & 0.18079 & 0.09451 & 0.15642 & 0.12086 & 0.12939 & 0 & 0 & 0 & 0 & 0 \\
\hline
\end{tabular}




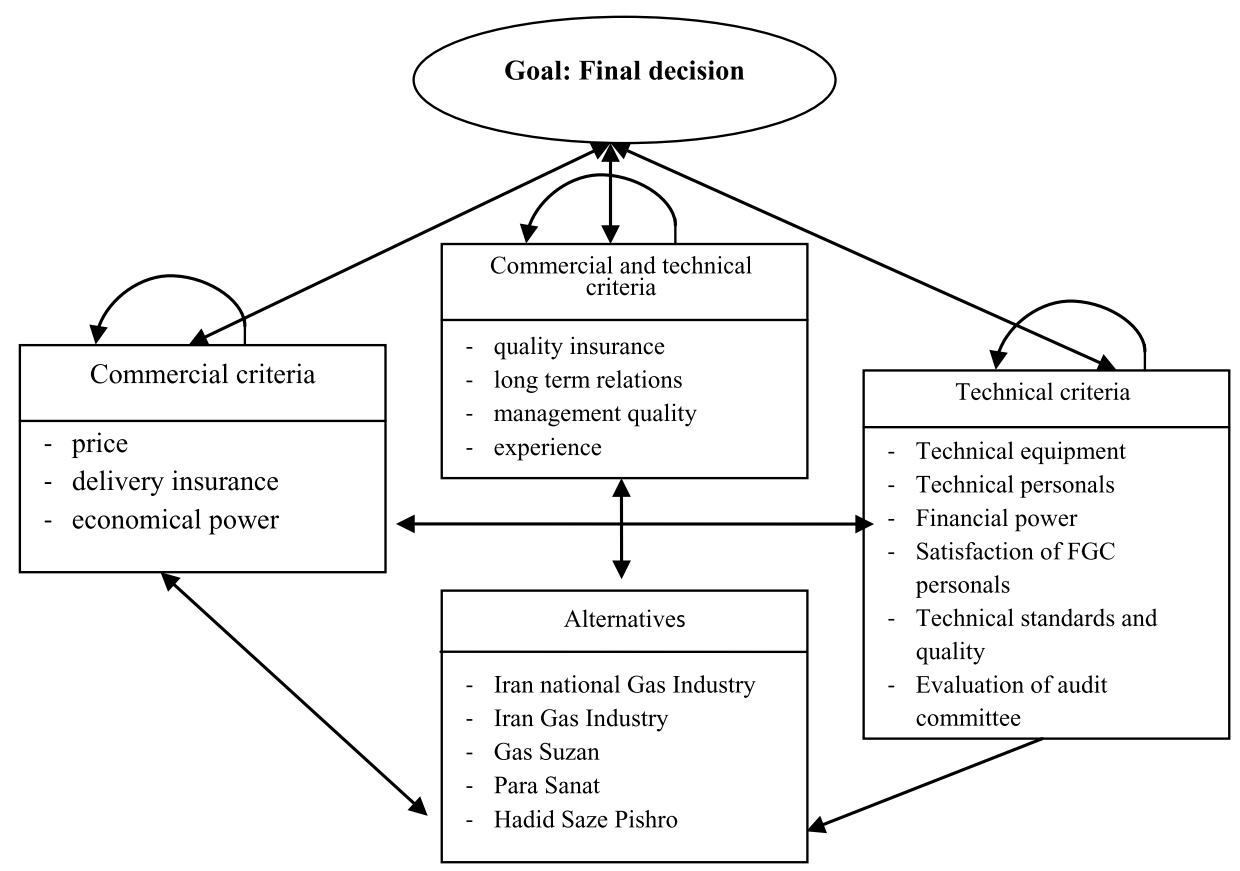

Fig. 6. The decision-making network for selecting supplier in FGC.

\section{Step 5. Calculating the weighted supermatrix (stochastic supermatrix)}

In the last part of the questionnaires, some questions were asked to find out the impact of the clusters on each other. The result of obtaining final comparison matrices and the ratio scale vectors are shown in Table 4 . Then to obtain the weighted supermatrix or stochastic supermatrix, the Table 4 entries are multiplied by the elements of their corresponding blocks in the supermatrix (Table 3). The weighted supermatrix is shown in Table 5 .

\section{Step 6. Calculating the final weights of the alternatives and the criteria}

In this stage, the powers of weighted supermatrix are calculated to obtain the limited supermatrix. After 17th iteration (17th power), the limited supermatrix is obtained as is shown in Table 6.

Each column of Table 6 determine the final ratio scale priority of elements in network. The final weight of each element and cluster is shown in Table 7. In this table, the cluster's ratio scale priority is equal to sum of its elements' ratio scale priority. The ratio scale priorities of the elements within their clusters (last column) are calculated by normalizing their ratio scale priority in the related cluster.

Table 7 indicates that the technical cluster has the most priority among all clusters in decision-making and within the technical cluster, the financial power factor has the most 
Table 4

The weight of blocks of decision network in decision-making for supplier selection in FGC

\begin{tabular}{llllll}
\hline & Goal & $\begin{array}{l}\text { Commercial } \\
\text { criteria }\end{array}$ & $\begin{array}{l}\text { Commercial and } \\
\text { technical criteria }\end{array}$ & $\begin{array}{l}\text { Technical } \\
\text { criteria }\end{array}$ & Alternatives \\
\hline Goal & 0 & 0 & 0 & 0 & 0 \\
Commercial criteria & 0.2623 & 0.209 & 0.2949 & 0.29 & 0.28401 \\
$\begin{array}{l}\text { Commercial and } \\
\text { technical criteria }\end{array}$ & 0.2816 & 0.281 & 0.1652 & 0.338 & 0.311494 \\
$\begin{array}{l}\text { Technical criteria } \\
\text { Alternatives }\end{array}$ & 0.4561 & 0.442 & 0.4423 & 0.29 & 0.404496 \\
\hline
\end{tabular}

priority in decision-making. Among the clusters, the commercial and technical cluster has the second most priority in decision-making within which the factor of management quality has the most priority in decision-making. The commercial cluster has the least priority in decision-making while the factor of economic power has the most priority within this cluster. Its interesting that the price factor priority (a criterion that previously was the only criterion for selecting the supplier) has the second priority within its cluster and has the fifth priority among all elements. The limited supermatrix indicates that FGC should select Gas Suzan (GS) as its supplier while before this study, Iran National Gas Industry (INGI) should have been selected based on considering the price factor.

\section{Conclusion}

Sometimes managers face the decision-making problems, which require specific techniques to deal with complexity and interactions among important factors to select the best alternative. ANP is one of techniques suggested to solve complex decision-making problems. In this study ANP technique is applied to select the supplier in a group decision making process. Using ANP in a real world problem showed that the managers of the intended company should modify their decision-making method while previous method leads to an unsuitable supplier. 
Table 5 (Part I)

The weighted supermatrix of decision-making for supplier selection in FGC

\begin{tabular}{lllllllllll}
\hline & & Goal & $\mathrm{p}$ & $\mathrm{DI}$ & $\mathrm{EP}$ & $\mathrm{QI}$ & $\mathrm{LR}$ & $\mathrm{MQ}$ & $\mathrm{E}$ & $\mathrm{TE}$ \\
\hline & Goal & 0 & 0 & 0 & 0 & 0 & 0 & 0 & 0 & 0 \\
\hline Commercial criteria & P & 0.135 & 0 & 0.08107 & 0.14459 & 0.08089 & 0.04999 & 0 & 0.13942 & 0.03946 \\
& DI & 0.06364 & 0.04294 & 0 & 0.06466 & 0.10701 & 0.12246 & 0.14746 & 0.05692 & 0.05964 \\
& EP & 0.06364 & 0.16631 & 0.12818 & 0 & 0.10701 & 0.12246 & 0.14746 & 0.09858 & 0.19118 \\
Commercial and & QI & 0.09903 & 0.03912 & 0 & 0.03569 & 0 & 0.05732 & 0 & 0.05265 & 0.06285 \\
technical criteria & LR & 0.03366 & 0.06777 & 0.1092 & 0.07314 & 0.03489 & 0 & 0.06386 & 0.05011 & 0 \\
& MQ & 0.08432 & 0.06389 & 0.1092 & 0.07819 & 0.08581 & 0.0683 & 0 & 0.06248 & 0.16531 \\
& E & 0.06464 & 0.11066 & 0.06305 & 0.09442 & 0.04454 & 0.03962 & 0.10138 & 0 & 0.10958 \\
Technical criteria & TE & 0.06254 & 0.12219 & 0.15046 & 0 & 0.08724 & 0.04926 & 0.08991 & 0 & 0 \\
& TP & 0.08055 & 0.0999 & 0.10869 & 0.18364 & 0.11941 & 0.05295 & 0.14778 & 0 & 0.10622 \\
& FP & 0.04712 & 0.08907 & 0.0814 & 0.16379 & 0.09444 & 0.0729 & 0.08206 & 0.21694 & 0.1833 \\
& SP & 0.06457 & 0 & 0.02936 & 0 & 0 & 0.07496 & 0 & 0 & 0 \\
Alternatives & TSQ & 0.10327 & 0.1308 & 0.07204 & 0.09454 & 0.14124 & 0.09137 & 0.12257 & 0.22538 & 0 \\
& EAC & 0.09803 & 0 & 0 & 0 & 0 & 0.10088 & 0 & 0 & 0 \\
& INGI & 0 & 0.01171 & 0.00577 & 0.00333 & 0.0213 & 0.02877 & 0.01314 & 0.02823 & 0.01523 \\
& IGI & 0 & 0.01154 & 0.01225 & 0.01411 & 0.03001 & 0.0135 & 0.03048 & 0.00898 & 0.02085 \\
& GS & 0 & 0.01475 & 0.03 & 0.02994 & 0.03116 & 0.03807 & 0.03594 & 0.03593 & 0.02412 \\
& PS & 0 & 0.0146 & 0.00707 & 0.00998 & 0.00735 & 0.0073 & 0.008 & 0.01155 & 0.01113 \\
& HSP & 0 & 0.01475 & 0.01225 & 0.00998 & 0.00769 & 0.00988 & 0.00995 & 0.01283 & 0.01113 \\
\hline
\end{tabular}


Table 5 (Part II)

The weighted supermatrix of decision-making for supplier selection in FGC

\begin{tabular}{|c|c|c|c|c|c|c|c|c|c|c|c|}
\hline & & $\mathrm{TP}$ & FP & SP & TSQ & $\mathrm{AD}$ & INGI & IGI & GS & PS & HSP \\
\hline & Goal & 0 & 0 & 0 & 0 & 0 & 0 & 0 & 0 & 0 & 0 \\
\hline \multirow[t]{3}{*}{ Commercial criteria } & $\mathrm{P}$ & 0.06508 & 0.21111 & 0 & 0.12715 & 0 & 0.15635 & 0.04995 & 0.08404 & 0.03879 & 0.0459 \\
\hline & DI & 0 & 0.02639 & 0.20747 & 0.0335 & 0.29028 & 0.06383 & 0.1117 & 0.09704 & 0.09501 & 0.11242 \\
\hline & EP & 0.2252 & 0.05278 & 0.08281 & 0.12963 & 0 & 0.06383 & 0.12236 & 0.10293 & 0.15022 & 0.12569 \\
\hline \multirow{4}{*}{$\begin{array}{l}\text { Commercial and } \\
\text { technical criteria }\end{array}$} & QI & 0.05437 & 0.06893 & 0.10822 & 0.08413 & 0.11889 & 0.05183 & 0.12061 & 0.07191 & 0.07278 & 0.0911 \\
\hline & LR & 0.06105 & 0.14473 & 0.06486 & 0.05474 & 0 & 0.10214 & 0.06033 & 0.06967 & 0.08881 & 0.07866 \\
\hline & MQ & 0.13876 & 0.12407 & 0.10822 & 0.13931 & 0.1631 & 0.05947 & 0.07646 & 0.0902 & 0.05701 & 0.07519 \\
\hline & $\mathrm{E}$ & 0.08355 & 0 & 0.05644 & 0.05954 & 0.05574 & 0.09805 & 0.0541 & 0.07971 & 0.0929 & 0.06655 \\
\hline \multirow[t]{6}{*}{ Technical criteria } & $\mathrm{TE}$ & 0.09815 & 0.15293 & 0.07106 & 0.07461 & 0.07127 & 0.07478 & 0.06426 & 0.0683 & 0.07184 & 0.06117 \\
\hline & $\mathrm{TP}$ & 0 & 0.13659 & 0.07226 & 0.09525 & 0.08338 & 0.08314 & 0.06318 & 0.07063 & 0.08355 & 0.08233 \\
\hline & FP & 0.19137 & 0 & 0.04729 & 0.06307 & 0.0515 & 0.06863 & 0.07574 & 0.06799 & 0.07931 & 0.06754 \\
\hline & SP & 0 & 0 & 0 & 0.025 & 0 & 0.04371 & 0.04838 & 0.05982 & 0.04536 & 0.06869 \\
\hline & TSQ & 0 & 0 & 0.09891 & 0 & 0.08338 & 0.06698 & 0.06029 & 0.0683 & 0.07908 & 0.07457 \\
\hline & $\mathrm{AD}$ & 0 & 0 & 0 & 0.03159 & 0 & 0.06726 & 0.09265 & 0.06946 & 0.04536 & 0.05018 \\
\hline \multirow[t]{5}{*}{ Alternatives } & INGI & 0.01235 & 0.01646 & 0.01543 & 0.01917 & 0.01741 & 0 & 0 & 0 & 0 & 0 \\
\hline & IGI & 0.01636 & 0.02186 & 0.01827 & 0.01951 & 0.01936 & 0 & 0 & 0 & 0 & 0 \\
\hline & GS & 0.02513 & 0.02876 & 0.0289 & 0.02435 & 0.02689 & 0 & 0 & 0 & 0 & 0 \\
\hline & PS & 0.01372 & 0.00759 & 0.00697 & 0.00946 & 0.00814 & 0 & 0 & 0 & 0 & 0 \\
\hline & HSP & 0.01491 & 0.00779 & 0.0129 & 0.00997 & 0.01067 & 0 & 0 & 0 & 0 & 0 \\
\hline
\end{tabular}


Table 6 (Part I)

The limited supermatrix of decision-making for supplier selection in FGC

\begin{tabular}{lllllllllll}
\hline & & Goal & $\mathrm{p}$ & $\mathrm{DI}$ & $\mathrm{EP}$ & $\mathrm{QI}$ & $\mathrm{LR}$ & $\mathrm{MQ}$ & $\mathrm{E}$ & TE \\
\hline & Goal & 0 & 0 & 0 & 0 & 0 & 0 & 0 & 0 & 0 \\
\hline Commercial criteria & P & 0.08622 & 0.08622 & 0.08622 & 0.08622 & 0.08622 & 0.08622 & 0.08622 & 0.08622 & 0.08622 \\
& DI & 0.06582 & 0.06582 & 0.06582 & 0.06582 & 0.06582 & 0.06582 & 0.06582 & 0.06582 & 0.06582 \\
& EP & 0.11721 & 0.11721 & 0.11721 & 0.11721 & 0.11721 & 0.11721 & 0.11721 & 0.11721 & 0.11721 \\
Commercial and & QI & 0.04775 & 0.04775 & 0.04775 & 0.04775 & 0.04775 & 0.04775 & 0.04775 & 0.04775 & 0.04775 \\
technical criteria & LR & 0.0649 & 0.0649 & 0.0649 & 0.0649 & 0.0649 & 0.0649 & 0.0649 & 0.0649 & 0.0649 \\
& MQ & 0.09364 & 0.09364 & 0.09364 & 0.09364 & 0.09364 & 0.09364 & 0.09364 & 0.09364 & 0.09364 \\
& E & 0.06712 & 0.06712 & 0.06712 & 0.06712 & 0.06712 & 0.06712 & 0.06712 & 0.06712 & 0.06712 \\
Technical criteria & TE & 0.07489 & 0.07489 & 0.07489 & 0.07489 & 0.07489 & 0.07489 & 0.07489 & 0.07489 & 0.07489 \\
& TP & 0.09774 & 0.09774 & 0.09774 & 0.09774 & 0.09774 & 0.09774 & 0.09774 & 0.09774 & 0.09774 \\
& FP & 0.10757 & 0.10757 & 0.10757 & 0.10757 & 0.10757 & 0.10757 & 0.10757 & 0.10757 & 0.10757 \\
& SP & 0.01275 & 0.01275 & 0.01275 & 0.01275 & 0.01275 & 0.01275 & 0.01275 & 0.01275 & 0.01275 \\
& TSQ & 0.07404 & 0.07404 & 0.07404 & 0.07404 & 0.07404 & 0.07404 & 0.07404 & 0.07404 & 0.07404 \\
& AD & 0.01412 & 0.01412 & 0.01412 & 0.01412 & 0.01412 & 0.01412 & 0.01412 & 0.01412 & 0.01412 \\
& & & & & & & & \\
Alternatives & INGI & 0.01377 & 0.01377 & 0.01377 & 0.01377 & 0.01377 & 0.01377 & 0.01377 & 0.01377 & 0.01377 \\
& IGI & 0.01668 & 0.01668 & 0.01668 & 0.01668 & 0.01668 & 0.01668 & 0.01668 & 0.01668 & 0.01668 \\
& GS & 0.0264 & 0.0264 & 0.0264 & 0.0264 & 0.0264 & 0.0264 & 0.0264 & 0.0264 & 0.0264 \\
& PS & 0.00914 & 0.00914 & 0.00914 & 0.00914 & 0.00914 & 0.00914 & 0.00914 & 0.00914 & 0.00914 \\
& HSP & 0.01023 & 0.01023 & 0.01023 & 0.01023 & 0.01023 & 0.01023 & 0.01023 & 0.01023 & 0.01023 \\
\hline
\end{tabular}


Table 6 (Part II)

The limited supermatrix of decision-making for supplier selection in FGC

\begin{tabular}{llllllllllll}
\hline & & TP & FP & SP & TSQ & AD & INGI & IGI & GS & PS & HSP \\
\hline & Goal & 0 & 0 & 0 & 0 & 0 & 0 & 0 & 0 & 0 & 0 \\
\hline Commercial criteria & P & 0.08622 & 0.08622 & 0.08622 & 0.08622 & 0.08622 & 0.08622 & 0.08622 & 0.08622 & 0.08622 & 0.08622 \\
& DI & 0.06582 & 0.06582 & 0.06582 & 0.06582 & 0.06582 & 0.06582 & 0.06582 & 0.06582 & 0.06582 & 0.06582 \\
& EP & 0.11721 & 0.11721 & 0.11721 & 0.11721 & 0.11721 & 0.11721 & 0.11721 & 0.11721 & 0.11721 & 0.11721 \\
Commercial and & QI & 0.04775 & 0.04775 & 0.04775 & 0.04775 & 0.04775 & 0.04775 & 0.04775 & 0.04775 & 0.04775 & 0.04775 \\
technical criteria & LR & 0.0649 & 0.0649 & 0.0649 & 0.0649 & 0.0649 & 0.0649 & 0.0649 & 0.0649 & 0.0649 & 0.0649 \\
& MQ & 0.09364 & 0.09364 & 0.09364 & 0.09364 & 0.09364 & 0.09364 & 0.09364 & 0.09364 & 0.09364 & 0.09364 \\
& E & 0.06712 & 0.06712 & 0.06712 & 0.06712 & 0.06712 & 0.06712 & 0.06712 & 0.06712 & 0.06712 & 0.06712 \\
Technical criteria & TE & 0.07489 & 0.07489 & 0.07489 & 0.07489 & 0.07489 & 0.07489 & 0.07489 & 0.07489 & 0.07489 & 0.07489 \\
& TP & 0.09774 & 0.09774 & 0.09774 & 0.09774 & 0.09774 & 0.09774 & 0.09774 & 0.09774 & 0.09774 & 0.09774 \\
& FP & 0.10757 & 0.10757 & 0.10757 & 0.10757 & 0.10757 & 0.10757 & 0.10757 & 0.10757 & 0.10757 & 0.10757 \\
& SP & 0.01275 & 0.01275 & 0.01275 & 0.01275 & 0.01275 & 0.01275 & 0.01275 & 0.01275 & 0.01275 & 0.01275 \\
& TSQ & 0.07404 & 0.07404 & 0.07404 & 0.07404 & 0.07404 & 0.07404 & 0.07404 & 0.07404 & 0.07404 & 0.07404 \\
& AD & 0.01412 & 0.01412 & 0.01412 & 0.01412 & 0.01412 & 0.01412 & 0.01412 & 0.01412 & 0.01412 & 0.01412 \\
& Alternatives & & & & & & & & \\
& INGI & 0.01377 & 0.01377 & 0.01377 & 0.01377 & 0.01377 & 0.01377 & 0.01377 & 0.01377 & 0.01377 & 0.01377 \\
& IGI & 0.01668 & 0.01668 & 0.01668 & 0.01668 & 0.01668 & 0.01668 & 0.01668 & 0.01668 & 0.01668 & 0.01668 \\
& GS & 0.0264 & 0.0264 & 0.0264 & 0.0264 & 0.0264 & 0.0264 & 0.0264 & 0.0264 & 0.0264 & 0.0264 \\
& PS & 0.00914 & 0.00914 & 0.00914 & 0.00914 & 0.00914 & 0.00914 & 0.00914 & 0.00914 & 0.00914 & 0.00914 \\
& HSP & 0.01023 & 0.01023 & 0.01023 & 0.01023 & 0.01023 & 0.01023 & 0.01023 & 0.01023 & 0.01023 & 0.01023 \\
\hline
\end{tabular}


Table 7

The relative importance of clusters and elements

\begin{tabular}{|c|c|c|c|c|}
\hline Clusters & Elements & $\begin{array}{l}\text { (1) } \\
\text { Ratio scale priority } \\
\text { in the network }\end{array}$ & $\begin{array}{l}\text { (2) } \\
\text { Ratio scale priority } \\
\text { of clusters }\end{array}$ & $\begin{array}{l}(3)=(1) /(2) \\
\text { Ratio scale priority of } \\
\text { of elements in their cluster }\end{array}$ \\
\hline \multirow[t]{3}{*}{ Commercial criteria } & $P$ & 0.08622 & \multirow[t]{3}{*}{0.269255} & 0.320215 \\
\hline & DI & 0.06582 & & 0.244456 \\
\hline & $\mathrm{EP}$ & 0.11721 & & 0.435329 \\
\hline \multirow{4}{*}{$\begin{array}{l}\text { Commercial and } \\
\text { technical criteria }\end{array}$} & QI & 0.04775 & \multirow[t]{4}{*}{0.273414} & 0.174662 \\
\hline & LR & 0.0649 & & 0.237359 \\
\hline & MQ & 0.09364 & & 0.342475 \\
\hline & $\mathrm{E}$ & 0.06712 & & 0.245504 \\
\hline \multirow[t]{6}{*}{ Technical criteria } & $\mathrm{TE}$ & 0.07489 & \multirow[t]{6}{*}{0.381107} & 0.1965 \\
\hline & $\mathrm{TP}$ & 0.09774 & & 0.256458 \\
\hline & FP & 0.10757 & & 0.282262 \\
\hline & SP & 0.01275 & & 0.033464 \\
\hline & TSQ & 0.07404 & & 0.194268 \\
\hline & $\mathrm{AD}$ & 0.01412 & & 0.037048 \\
\hline \multirow[t]{5}{*}{ Alternatives } & INGI & 0.01377 & \multirow[t]{5}{*}{0.076224} & 0.180655 \\
\hline & IGI & 0.01668 & & 0.218892 \\
\hline & GS & 0.0264 & & 0.346346 \\
\hline & PS & 0.00914 & & 0.119888 \\
\hline & HSP & 0.01023 & & 0.134218 \\
\hline
\end{tabular}

\section{References}

Akarte, M.M., Surendra, N.V., Ravi, B., Rangaraj, N. (2001). Web based casting supplier evaluation using analytical hierarchy process. Journal of the Operational Research Society, 52(5), 511-522.

Azar, A., Rajabzadeh, A. (2002). Applied decision-making (M.A.D.M approach). Negah Danesh, Tehran.

Azis, Iwan J. (2003). Analytic network process with feedback influence: a new approach to impact study. Prepared for a seminar organized by the Department of Urban and Regional Planning, University of Illinois at Urbana-Champaign, in conjunction with the Investiture Ceremony for Professor John Kim. http: / /www. iwanazis.net/papers/Azis-JKIM-Paper.pdf.

Bauyaukyazici, M., Sucu, M. (2003). The analytic hierarchy and analytic network processes. Hacettepe Journal of Mathematics and Statistics, 32, 65-73.

Bayazit, O. (2006). Use of analytic network process in vendor selection decisions. Benchmarking: An International Journal, 13(5), 566-579.

Bevilacqua,M., Ciarapica, F.E., Giacchetta, G. (2006). A fuzzy-QFD approach to supplier selection. Journal of Purchasing and Supply Management, 12(1), 14-27.

Cebi, F., Bayraktar, D. (2003). An integrated approach for supplier selection. Logistics Information Management, 16(6), 395-400.

Chan, F.T.S., Chan, H.K. (2004). Development of the supplier selection model - a case study in the advanced technology industry. In: Proceedings of the Institution of Mechanical Engineers Part B - Journal of Engineering Manufacture, 218(12), 1807-1824.

Chan, F.T.S., Kumar, N. (2007). Global supplier development considering risk factors using fuzzy extended AHP-based approach. OMEGA, 35(4), 417-431. 
Chen, C.T., Lin, C.T., Huang, S.F. (2006). A fuzzy approach for supplier evaluation and selection in supply chain management. International Journal of Production Economics, 102(2), 289-301.

Chen, H.H., Lee, A.H.I., Tong, Y. (2007). Prioritization and operations NPD mix in a network with strategic partners under uncertainty. Expert Systems with Applications, 33(2), 337-346.

Christopher, M. (1992). Logistics and Supply Chain Managemen: Strategies for Reducing Costs and Improving Services. Pitman Publishing, London.

Demirtas, E.A., Ustun, O. (2008). An integrated multi-objective decision making process for supplier selection and order allocation. OMEGA, 36(1), 76-90.

Demirtas, E.A., Ustun, O. (2009). Analytic network process and multi-period goal programming integration in purchasing decisions. Computer and Industrial Engineering, 56(2), 677-690.

Esain, A., Hines, P. (1997). Regional innovation through inter-company networking: evidence from wales. In: Proceedings of the 3rd International Symposium on Logistics, University of Padua, Padua, 77-86.

Gencer, C., Gurpinar, D. (2007). Analytic network process in supplier selection: a case study in an electronic firm. Applied Mathematical Modeling, 31(11), 2475-2486.

Ha, S.H., Krishnan, R. (2008). A hybrid approach to supplier selection for the maintenance of a competitive supply chain. Expert Systems with Applications, 34(2), 1303-1311.

Harland, C. (1996). Supply Network Strategies. European Management Journal, 21, 642-654.

Hines, P. (1997). Toyota supplier system in Japan \& the UK. In: Proceedings of the Third International Symposium on Logistics, University of Padua, Padua, pp. 87-96.

Hou, J., Su, D. (2007). EJB-MVC oriented supplier selection system for mass customization. Journal of Manufacturing Technology Management, 18(1), 54-71.

Hsu, T., Pan, F.F.C. (2009). Application of Monte Carlo AHP in ranking dental quality attributes, Part 1. Expert Systems with Applications, 36(2), 2310-2316.

Hu, H., Liang, W., Guo, A., An, X., Zhou,P., Wang, J., Lin, Y. (2008). Automated management and evaluation system for community health service. Kybernetes, 37(9/10) 1359-1366.

Huang, H. (2009). Designing a knowledge-based system for strategic planning: a balanced scorecard perspective. Expert Systems with Applications, 36(1) 209-218.

Huang, L., Chen, K.H., Wu, Y.W. (2009). What kind of marketing distribution mix can maximize revenues: the wholesaler travel agencies' perspective? Tourism Management, 30(5) 733-739.

Koszewska, M. (2004). Outsourcing as a modern management strategy prospects for its development in the protective clothing market. AUTEX Research Journal, 4, 348-367.

Kull, T.J., Talluri, S. (2008). A supply-risk reduction model using integrated multicriteria decision making. IEEE Transactions on Engineering Management, 55(3), 409-419.

Kuo, Y., Yang,T., Cho, C., Tseng, Y.C. (2008). Using simulation and multi-criteria methods to provide robust solutions to dispatching problems in a flow shop with multiple processors. Mathematics and Computers in Simulation, 78(1), 40-56.

Lang, T.M., Chiang, J.H., Lan, L.W. (2009). Selection of optimal supplier in supply chain management strategy with analytic network process and choquet integral. Computers \& Industrial Engineering, 57, 330-340

Lee, A.H.I., Chang, H.J., Lin, C.Y. (2009a). An evaluation model of buyer-supplier relationships in high-tech industry - the case of an electronic components manufacturer in Taiwan. Computers \& Industrial Engineering, 57, 1417-1430

Lee, H., Lee, S., Park, Y. (2009b). Selection of technology acquisition mode using the analytic network process. Mathematical and Computer Modelling, 49(5-6), 1274-1282.

Levary, R.R. (2008). Using the analytic hierarchy process to rank foreign suppliers based on supply risks. Computers \& Industrial Engineering, 55(2), 535-542.

Li, J., Zhang, H.C., Gonzalez, M.A., Yu, S. (2008). A multi-objective fuzzy graph approach for modular formulation considering end-of-life issues. International Journal of Production Research, 46(14), 4011-4033.

Li, Q.X., Liu, S.F. (2008). The foundation of the grey matrix and the grey input-output analysis. Applied Mathematical Modeling, 32(3), 267-29.

Liao, S.K., Chang, K.L., Tseng, T.W. (2010). Optimal selection of program suppliers for TV companies using an Analytic Network Process (ANP) approach. Asia-Pacific Journal of Operational Research (APJOR), 27(6), $753-767$.

Lin, C.T., Chen, C.B., Ting, Y.C. (2011). An ERP model for supplier selection in electronics industry. Expert Systems with Applications, 38, 1760-1765

Lin, R., Lin, J.J., Shu, C.J., Diodes, T., Chao, H., Peter, J.C. (2008). Note on group consistency in analytic 
hierarchy process. European Journal of Operational Research, 190(3), 627-678.

Liu, F.H.F., Hai, H.L. (2005). The voting analytic hierarchy process method for selecting supplier. International Journal of Production Economics, 97(3), 308-317.

Meade, L., Sarkis, J. (1998). Strategic analysis of logistics and supply chain management systems using the analytical network process. Logistics and Transportation Review, 34(3), 201-215.

Mendoza, A., Ventura, J.A. (2008). An effective method to supplier selection and order quantity allocation. International Journal of Business and Systems Research, 2(1), 1-15.

Muralidharan, C., Anantharaman, N., Deshmukh, S.G. (2002). A multi-criteria group decision-making model for supplier rating. Journal of Supply Chain Management, 38(4), 22-33.

Ozturk, Z.K. (2006). A review of multi-criteria decision-making with dependency between criteria. MultiCriteria Decision Making, 5, 19-29.

Percin, S. (2006). An application of the integrated AHP-PGP model in supplier selection. Measuring Business Excellence, 10(4), 34-49.

Porter, M. (1985). Competitive Advantage: Creating and Sustaining Superior Performance. The Free Press, New York.

Quelin, B, Duhamel, F. (2003). Bringing together strategic outsourcing and corporate strategy: outsourcing motives and risks. European Management Journal, 21(5), 652.

Ramanathan, R. (2007). Supplier selection problem: Integrating DEA with the approaches of total cost of ownership and AHP. Supply Chain Management: An International Journal, 12(4), 258-261.

Saaty, T.L. (1996a). Decision Making with Feedback: The Analytical Network Process. RWS Publications, Pittsburg.

Saaty, T.L. (1996b). Decision-making for leaders: the analytical hierarchy process for decisions in a complex world. The Analytical Hierarchy Process, 2, 71-74.

Saaty, T.L, Vargas, L.G. (2006). Decision-Making with the Analytic Network Process Economic, Political, Social and Technological Applications with Benefits, Opportunities, Costs and Risks. Springer, New York.

Saaty, T.L, Takizawa, M. (1986). Dependence and independence : from linear hierarchies to nonlinear network. European Journal of Operation Research, 26(2), 229-237.

Saen, R.F. (2007). A new mathematical approach for supplier selection: accounting for non-homogeneity is important. Applied Mathematics and Computation, 185(1), 84-95.

Sarkis, J., Talluri, S. (2002). A model for strategic supplier selection. Journal of Supply Chain Management, $38(1), 18-28$.

Sevkli, M., Koh, S.C.L., Zaim, S., Demirbag, M., Tatoglu, E. (2007a). An application of data envelopment analytic hierarchy process for supplier selection: a case study of BEKO in Turkey. International Journal of Production Research, 45(9), 1973-2003.

Sevkli, M., Lenny Koh, S.C., Zaim, S., Demirbag, M., Tatoglu E. (2007b). An application of data envelopment analytic hierarchy process for supplier selection: a case study of BEKO in Turkey, International Journal of Production Research, 45(9), 1973-2003.

Sun, Y., Ma, J., Fan, Z.P., Wang J. (2008). A group decision support approach to evaluate experts for R\&D project selection. IEEE Transactions on Engineering Management, 55(1), 158-170.

Tsai, W., Hung, S. (2009). Dynamic pricing and revenue management process in internet retailing under uncertainty: an integrated real options approach. Omega, 37(2), 471-481.

Wang, G., Huang, S.H., Dismukes, J.P. (2004). Product-driven supply chain selection using integrated multicriteria decision-making methodology. International Journal of Production Economics, 91(1), 1-15.

Wang, G., Huang, S.H., Dismukes, J.P. (2005). Manufacturing supply chain design and evaluation. International Journal of Advanced Manufacturing Technology, 25(1-2), 93-100.

$\mathrm{Xia}, \mathrm{W} ., \mathrm{Wu}, \mathrm{Z}$. (2007). Supplier selection with multiple criteria in volume discount environments. OMEGA, 35(5), 494-504.

$\mathrm{Xu}, \mathrm{Z}$. (2000). On consistency of the weighted geometric mean complex judgment matric in AHP. European Journal of Operational Research, 126(3), 683-687.

Yang, C.C., Chen, B.S. (2006). Supplier selection using combined analytical hierarchy process and grey relational analysis. Journal of Manufacturing Technology Management, 17(7), 926-941. 
M. Sadeghi received BS degree in industrial management at Shiraz Azad University, Shiraz Iran. He received MS degree in management at Shiraz University, Shiraz, Iran. $\mathrm{He}$ is currently working towards $\mathrm{PhD}$ degree at Allame Tabatabaei University, Tehran, Iran. His research interest is optimization, production management and planning and he teaches operational research, statistics and its applications in management and decision making theory in Allame Tabatabaei University.

M. ali Rashidzadeh had received BS degree in management at Tehran University, Tehran, Iran. He received MS degree in MBA in Kansas State University, the PhD degree in management was received from University of Colorado. Dr. Rashidzadeh is one of the assistant professors is Shiraz University and the main courses that he teaches are: research method, human resource management, marketing and organization and management theory.

M. ali Soukhakian is assistant professors in Shiraz University and his main interesting area for teach and research are: applied statistics, operational research, optimization modeling and decision making theory.

\section{Tiekejjo atranka, taikant analitinio tinklo procesu sprendimams grupèse priimti}

Mohammadreza SADEGHI, Mohammad ali RASHIDZADEH, Mohammad ali SOUKHAKIAN

Turintys didžiausią paklausą produktai ir paslaugos šiandien tiekiami per kitas organizacijas. Darbu perkèlimas ị kitą firmą yra naujas reiškinys, kuris yra plačiai nagrinèjamas literatūroje. Vadovai pasirenka tiekejją tada, kai organizacija nusprendžia nusipirkti produktą ar paslaugą iš kitos organizacijos. Pasirenkant tiekéją vadovai turètų taikyti daugiau, nei vieną veiksnị ar kriterijų, tačiau jie gali būti nesuderinami ar prieštaringi. Analitinio tinklo procesas (ATP) - tai yra nauja metodika, leidžianti išspręsti sprendimų prièmimo uždavinius, kuriuose kriterijai turi poveiki vienas kitam ir tarp kriteriju yra netiesiné koreliacija. Šio tyrimo tikslas yra tiekejo atranka, taikant ATP metodiką sprendimams grupèse priimti. 
